Zabytkoznawstwo i Konserwatorstwo XLIV, Toruń 2013

\title{
Warsztat malarski Pietera Meulenera \\ na przykładzie obrazu \\ Potyczka jeźdźców w krajobrazie (1647 r.) \\ z Muzeum Narodowego w Poznaniu oraz innych dzieł malarza znajdujących się w zbiorach polskich*
}

\section{Wstęp}

Zachowane do dziś obrazy flamandzkich malarzy XVII wieku cechuje doskonała jakość wykonania. Przetrwały one do naszych czasów w dobrym stanie, co wynika przede wszystkim z przestrzegania określonych reguł, jakim podlegało ówczesne malarstwo. Artyści flamandzcy musieli bowiem mieć nie tylko wrodzone poczucie estetyki i ducha artyzmu, ale także doskonale opanowaną znajomość rzemiosła. Dobrze oczyszczone oleje, staranne przygotowanie farb i dobór odpowiednich materiałów malarskich miały niebagatelny wpływ na trwałość ich prac. Doskonałym tego przy-

* W niniejszym artykule wykorzystano materiały zawarte w pracy magisterskiej: M. Kapka, Potycžka jeźdźcón w krajobraz̨ie na tle XVII-wiecznego malarstwa flamandzkiego, Toruń 2008 (IZK, UMK), wykonanej pod kierunkiem dr hab. Elżbiety Basiul w Zakładzie Technologii i Technik Malarskich 
kładem jest twórczość Pietera Meulenera ${ }^{1}$. W artykule przedstawiono analizę budowy technicznej obrazów: Potyczৃa jeźdźcón w krajobraz̨ie z 1647 roku ze zbiorów Muzeum Narodowego w Poznaniu², Potyczka z Muzeum Narodowego w Warszawie oraz Krajobraz ze sztafażem batalistycznym z 1646 roku z Muzeum Narodowego w Gdańsku. W przypadku obrazów z Warszawy i Gdańska nie wykonano tak szczegółowych badań, jakim poddano obraz z poznańskiego muzeum, natomiast przeprowadzono dokładna analizę wizualną, na podstawie której zaobserwowano dość duże analogie, zarówno pod względem stylistyczno-formalnym, jak i sposobu wykonania obrazów. W celu uzyskania jak najpełniejszej wiedzy na ten temat techniki i technologii malarstwa flamandzkiego XVII wieku, w tym warsztatu Pie-

1 Pieter Meulener (Meulenaer, Molenaer) urodził się w 1602 roku w Antwerpii. Wiedzę o malarstwie zdobył od swego ojca i jako syn mistrza w 1631 roku wstapił do Antwerpskiej gildii Świętego Łukasza. Zmarł w 1654 roku w Antwerpii, gdzie 27 listopada został pochowany w kościele św. Andrzeja. Meulener był malarzem krajobrazów, scen polowań i obrazów historycznych, przedstawiających głównie bitwy i potyczki, ukazanych zazwyczaj w bogatej scenerii krajobrazowej, a także na tle znanych miast. Przeważająca część jego obrazów, sygnowanych i datowanych, została przechowana i ocalona przez Antwerpski Dom Forchondtów, a potem eksportowana do Wiednia i Lizbony. Jego obrazy wzbogacają galerie wielu światowej klasy muzeów, m.in. paryskiego Luwru, Rijksmuseum w Amsterdamie, Ermitażu w Sankt Petersburgu, Prado w Madrycie, Nationalmuseum w Sztokholmie, Groeninge Museum w Brugii, Muzeum Narodowego w Pradze, a także muzeów w Bremie, Hermannstadzie, Brunszwiku i Lubece, J. de Maere, M. Wabbes, Ilustrated Dictionary of 17 century Flemish Painters, Brussels 1994, s. 277-278; Dictionnaire des Peintres belgies, notka biograficzna opracowana przez R. van Dooren [dokument elektroniczny], tryb dostępu: http://balat.kikirpa.be/Detail_notice.php?id=3871 (01.02.2012). W Polsce jego obrazy znajdują się w Muzeach Narodowych w Warszawie, Poznaniu oraz Gdańsku. Potyczka jeźdźcón w krajobražie została prawdopodobnie namalowana w Antwerpii, gdzie przez całe życie autor mieszkał i tworzył. Więcej informacji na temat życia i twórczości Pietera Meulenera oraz jego twórczych inspiracji znajduje się w pracy magisterskiej, patrz przyp. gwiazdkowy.

2 Obraz został poddany różnorodnym badaniom fizycznym oraz mikrochemicznym, były to m.in.: analiza w świetle VIS oraz fluorescencji powierzchni obrazu wzbudzonej promieniami UV, analiza zdjęć obrazu w promieniach IR oraz kolorowej podczerwieni, badanie RTG, spektrometria XRF, badania na przekrojach pobranych próbek. Dobry stan zachowania lica obiektu nie pozwolił na wypreparowanie z obiektu wystarczającej ilości materiału badawczego, co w niektórych przypadkach ograniczyło zakres przeprowadzonych badań. Szczegółowy przebieg badań znajduje się w pracy magisterskiej, patrz przyp. gwiazdkowy. 
tera Meulenera, dokonano także przeglądu dzieł innych flamandzkich malarzy tego okresu $\mathrm{w}$ muzeach ${ }^{3}$, skupiając się na przedstawieniach krajobrazów ze sztafażem. Ponadto zebrano informacje zawarte w dokumentacjach konserwatorskich i innych opracowaniach naukowych. Spośród literatury źródłowej powoływano się głównie na XVII-wieczny traktat Theodore'a Turqueta de Mayerne'a Pictoria, Sculptoria et quae subalternarum atrium, gdzie znaleziono istotne dane na temat technicznej strony niderlandzkiego malarstwa. Niniejszy artykuł może stanowić pewien wkład w zagadnienie analizy techniczno-technologicznej obrazów „małych mistrzów flamandzkich”, które pozostaje w cieniu o wiele obszerniejszych badań nad twórczością najsłynniejszego flamandzkiego malarza tego okresu - Rubensa, co można tłumaczyć ogromnym wpływem jego warsztatu na całe malarstwo flamandzkie XVII wieku. Zaprezentowane poniżej wyniki badań poparto uzyskanymi informacjami dotyczącymi warsztatu flamandzkich malarzy XVII wieku, ale ze względu na ich obszerność poruszono tylko najistotniejsze kwestie, które zamieszczono w przypisach ${ }^{4}$.

\section{Technika i technologia Potyczki jeźdźców w krajobrazie z Muzeum Narodowego w Poznaniu}

Drewniane podobrazie o wymiarach $32,5 \times 41 \mathrm{~cm}$ wykonane zostało z dwóch promieniowo ciętych desek o wymiarach: 8 x $41 \mathrm{~cm} \mathrm{i} 24,5$ x $41 \mathrm{~cm}$,

\footnotetext{
Oględzinom poddano flamandzkie obrazy z Muzeum Narodowego w Poznaniu, z Muzeum Narodowego w Warszawie i w Gdańsku, a przede wszystkim obrazy prezentowane na wystawie Złoty wiek malarstwa flamandzkiego, która oprócz kilkunastu obrazów ze zbiorów Kunsthistorisches Museum i Akademie der Bildenden Künste w Wiedniu zgromadziła kilkadziesiąt obrazów z polskich kolekcji, m.in. Fundacji Czartoryskich, Fundacji Raczyńskich, Zamku na Wawelu i Zamku Królewskiego w Warszawie oraz prawie wszystkich muzeów narodowych w Polsce. Na tej wystawie dokonano wizualnej analizy m.in. prac Rubensa i van Dycka z wczesnego okresu ich twórczości.

4 Więcej informacji na ten temat znajduje się w pracy magisterskiej w rozdziale pt. „Warsztat flamandzkich malarzy XVII wieku w świetle badań i literatury - porównanie z techniką wykonania Potyczkei jeźdźcón w krajobrąie”, patrz przyp. gwiazdkowy.
} 
które zostały ze sobą sklejone na styk ${ }^{5}$. Na odwrociu Potycz̨iki jeźdźcón $w$ krajobrazie widoczne jest tylko jedno, płytkie sfazowanie deski o szerokości $2 \mathrm{~cm}$ przy górnej krawędzi. Nie wiadomo jednak, czy brak faz z trzech pozostałych stron nie jest wynikiem np. późniejszego niewielkiego zmniejszenia formatu obrazu w celu dopasowania go do nowej ramy. Wiadomo bowiem, że krawędzie podobrazi w tych czasach fazowano, przeciętnie na szerokość $2-4,5 \mathrm{~cm}$, aby zabezpieczyć je przed paczeniem (ograniczenie powierzchni sztorców) i dobrze umocować obraz w ramie ${ }^{6}$. Na odwrociu widnieją charakterystyczne żłobienia o kierunku poprzecznym do układu włókien drewna (fot. 3). Niewykluczone, że są to ślady po obróbce piłą bądź innym ostrym narzędziem (prawdopodobnie strugiem). Żłobienia te wykonane zostały jeszcze przed sklejeniem dwóch części desek, gdyż ich rowki na obu deskach nie pokrywają się z sobą, ponadto te na desce górnej są głębsze. Widoczne są także nikłe ślady po wypaleniu, które mogą być pozostałościami po znaku cechowym. Na podstawie braku fluorescencji odwrocia w świetle UV można przypuszczać, iż nie zostało ono pokryte żadną izolacja. Dobry stan zachowania drewna uniemożliwił pobranie odpowiedniej ilości próbek do identyfikacji gatunku drewna. Jednak na podstawie analizy wizualnej oraz porównawczej, a także na podstawie zebranych informacji na temat techniki autora obrazu można stwierdzić, że obie deski wykonane zostały z drewna dębowego?

5 Podłoża drewniane, nawet te mniejszego formatu, rzadko składały się z jednego kawałka deski, która jeśli nie była wycięta promieniowo, miała większą skłonność do deformacji niż deski klejone razem. Tak np. tablice Rubensa składają się zwykle z wielu klejonych ze sobą części podobrazia, do których zdarzało mu się dosztukowywać dodatkowe przy powiększaniu kompozycji już w trakcie malowania, por. J. Kirby, The Painter's Trade in the Seventeenth Century: Theory and Practice, "National Gallery Technical Bulletin" 1999, Vol. 20: Painting in Antwerp and London: Rubens and Van Dyck, s. 21-22.

6 E. Szmit-Naud, Krajobraz Leśny ₹. Muгeum Narodowego w Poznaniu - badania materiatón $i$ techniki, „AUNC. Zabytkoznawstwo i Konserwatorstwo” XXIV, Toruń 1994, s. 120.

7 Konsultacje przeprowadzone z prof. dr. hab. T. Ważnym z Zakładu Technologii i Technik Malarskich UMK w Toruniu potwierdziły tę tezę. Drewno dębowe miało tę zaletę, że było dość odporne na czynniki niszczące i z tego powodu stosowane było przede wszystkim w niderlandzkim wilgotnym klimacie nadmorskim. Dendrochronologiczne dowody wskazują na to, że od XV wieku lub wcześniej aż do 1650 roku było ono importowane, głównie ze wschodnich regionów nadbałtyckich, zazwyczaj w postaci płyt lub desek, a Gdańsk był głównym ośrodkiem jego eksportu, por. J. Kirby, op. cit., s. 18. 
$\mathrm{Na}$ deskę naniesiono dwie warstwy białej zaprawy kredowo-klejowej z domieszką bieli ołowiowej ${ }^{8}$. Nie udało się ustalić, czy podłoże zostało wcześniej przeklejone. Jest ona jednorodna i nie zawiera pęcherzyków powietrza, natomiast brak spękań świadczy o tym, że stężenie kleju w zaprawie było prawidłowe. Zaprawa wykazuje dobra przyczepność do podłoża. Jej dość cienka warstwa sprawia, że miejscami na powierzchni lica widoczne sa poziome włókna drewna i pozostałości pożółkłego werniksu, co spowodowało zafałszowanie ogólnej kolorystyki obrazu. Pierwsza warstwa nałożona została prawdopodobnie za pomocą szpachli na zimno i miała konsystencja żelu, o czym może świadczyć dobre wypełnienie porów drewna?. Fakt, że nie na wszystkich przekrojach podział między warstwami jest widoczny, może świadczyć o tym, iż drugą warstwę malarz nakładał na nie do końca wyschniętej spodniej warstwie. $\mathrm{Na}$ licu malowidła w oświetleniu bocznym, w miejscach transparentnej warstwy malarskiej widoczna jest delikatna faktura powierzchni zaprawy, co może świadczyć o tym, że drugą warstwę zaprawy naniesiono pędzlem. Natomiast jej dość regularna linia, widoczna na przekrojach, może wskazywać na to, że zaprawę po wyschnięciu delikatnie przeszlifowano. Niemal na całej powierzchni lica obrazu zaobserwować można „przebijające” przez warstwę malarską „ziarenka” wypełniaczy zaprawy (kredy lub/i bieli ołowiowej). Badania nie wykazały obecności warstwy imprimatury ${ }^{10}$. $\mathrm{Na}$ podstawie analizy przekrojów udało

8 Do gruntowania na drewnie de Mayerne poleca m.in. zaprawę z kredy i kleju cielęcego lub koźlęcego, którą po wyschnięciu radzi zeskrobać i wyrównać nożem, a potem nanieść cienką warstwę bieli ołowiowej z umbra, E. Berger, Quellen für Maltechnik während der Renaissance und deren Folgezeit, München 1901, s. 117. Na stronach 99-365 autor zamieszcza pełen tekst traktatu T. T. De Mayerne'a, Pictoria, Sculptoria et quae subalternarum atrium, 1620.

9 J. Flik, M. Wiącek, Przedstawienie św. Hieronima wedtug Albrechta Dürera, „AUNC. Zabytkoznawstwo i Konserwatorstwo" XXI, Toruń 1994, s. 62. Autorzy za Z. Brochwiczem twierdza, że założenie ciepłej zaprawy wywołałoby szybką deformację podobrazia.

10 De Mayerne białą zaprawę na desce zaleca tonować cienka, olejną warstwa z bieli ołowiowej i umbry, E. Berger, op. cit., s. 117, 261. Warstwa ta mogła spełniać zarówno rolę izolacyjną oraz kolorystyczną, tonująca. U Rubensa była to warstwa naniesiona swobodnie, z pozostawieniem wyraźnych smug, składająca się z brązu, ugru oraz bieli ołowiowej. $\mathrm{Na}$ deskach Rubensa i van Dycka w kolekcji londyńskiej Galerii Narodowej, które zostały zbadane, warstwa ta okazała się zbyt cienka, aby zidentyfikować jej spoiwo (udało się to w przypadku Samsona i Dalili Rubensa, gdzie zidentyfikowano spoiwo olejne). Prawdopodobnie była ona rutynowo stosowana przez twórców tablic malarskich lub specjalistów od 
się w kilku przypadkach zidentyfikować bardzo cienką warstwę leżącą bezpośrednio na zaprawie ${ }^{11}$. Jest to zapewne wstępny rysunek lawowany, którym malarz stworzył kompozycyjny szkic pni i gałęzi drzew oraz delikatnie zaznaczył rysunek sztafażu. Fotografia lica w podczerwieni nie wykazała bowiem istnienia rysunku, najciemniejsze miejsca są prawdopodobnie największymi skupiskami czerni i pokrywają się z najciemniejszymi miejscami widocznymi w świetle widzialnym ${ }^{12}$.

W warstwie tej zidentyfikowano czerń organiczna - sadzę, czerwień żelazową oraz ugier. Spoiwem warstwy jest olej schnący, a wyraźne pociemnienie w wyniku rekcji z $\mathrm{Na}_{2} \mathrm{~S}$ może świadczyć o dodaniu do niej sykatywy ołowiowej bądź miedziowej. Po wstępnym przygotowaniu podłoża artysta przystapił do właściwego opracowywania poszczególnych warstw malarskich. Warstwy te nakładane były dość cienko, o czym świadczą m.in. wspomniane „przebijające” przez nie białe drobiny pigmentów zaprawy. Sadząc po widocznych duktach pędzla, można przypuszczać, że w czasie malowania używał najczęściej pędzli o niewielkich grubościach włosia (w dzisiejszej numeracji 1-6). Najcieńszych, okragłych użył do opracowania drobnych elementów sztafażu i roślinności (źdźbła trawy, małe gałązki drzew), natomiast najszerszego, płaskiego do partii nieba. Z kolei okragłym pędzlem o rozszczepionych końcówkach stworzył drobne impasty na kępach drzew dalszego planu. Pigmenty, jakich artysta użył do namalowania obrazu, była ograniczona ${ }^{13}$. Badania wykazały obecność kredy i bieli ołowiowej

gruntowania (tzw. witter). Artysta mógł o nią poprosić lub wykonać samodzielnie w pracowni, J. Kirby, op. cit., s. 27.

11 Zgodnie z tym, co pisze Van Mander, za jego czasów w obrazach mistrzów niderlandzkich olejna „cielistą” imprimaturę (primuersel) nanoszono bezpośrednio na zaprawę, po uprzednim wykonaniu rysunku. Natomiast w obrazach włoskich XVI wieku, zdaniem Vasariego, barwna, olejna imprimatura znajdowała się pod rysunkiem i tę właśnie kolejność można odnaleźć w obrazach malarzy flamandzkich czasów de Mayerne’a, co jest jednym ze świadectw wpływu włoskiej tradycji, E. Berger, op. cit., s. 37.

12 Rysunek u Rubensa polegał na swobodnym podmalowaniu zarysu kompozycji przy użyciu ugru lub umbry na spoiwie klejowym bądź olejnym, por. F. Decker, Historische Maltechniken und Kopie, Dresden 1983, s. 74-76.

13 Do pigmentów używanych w XVII wieku przez flamandzkich artystów należały: ultramaryna i azuryt, źółte, czerwone i brązowe pigmenty mineralne, pigmenty przemysłowe, takie jak cynober (który również występował naturalnie), biel ołowiowa, minia, żółcień ołowiowo-cynowa, smalta i miedzianka, czerwone i żółte laki, indygo naturalne oraz róż- 
(prawdopodobnie występującej pod postacią mieszanki o nazwie lootwit lub ceruse $^{14}$ ), błękitu miedziowego (azurytu, czyli tzw. błękitu popiołowego ${ }^{15}$ ), smalty, zielonego pigmentu miedziowego (miedzianki), czerwieni żelazowej i cynobru, ugru, czerni organicznej - sadzy oraz brąowych pigmentów żelazowych (umbry naturalnej i palonej, możliwe, że także sieny). Fotografia wykonana w technice „fałszywych kolorów” zdradza użycie także czerwonego pigmentu organicznego - m.in. pióropusz jeźdźca z lewej strony jest wyraźnie pomarańczowy, co jest charakterystyczne dla czerwonych laków ${ }^{16}$.

Mimo iż nie potwierdziły tego przeprowadzone badania, niewykluczone jest zastosowanie przez malarza również żółtych, zielonych oraz brązowych pigmentów organicznych (asfaltów lub bitumów). Spoiwem wymienionych pigmentów był olej schnący ${ }^{17}$ oraz medium olejno-żywiczne ${ }^{18}$.

ne pigmenty czarne. Zwiększało się również zastosowanie sztucznie przygotowanych niebieskich i zielonych pigmentów miedzianych, por. J. Kirby, op. cit., s. 30. Według de Mayerne’a pigmenty, które nadają się do malarstwa olejnego, to: biel ołowiowa, czerń lampowa, cynober, czerwony lak do laserunków, minia (nie jest według niego zbyt dobra do oleju, ale sykatywuje np. cynober albo lak), brunatnoczerwona angielska czerwień, żółta ochra palona, żółty Schüttgelb (ang. Pinke), masykot, umbra naturalna i palona, błękit popiołowy (inaczej nazywa go azuryt, błękit górski), smalta, ultramaryna z lapis lazuli, ziemia zielona. Wymienia również miedziankę destylowana, jednak radzi stosować ją tylko do laserunków. Natomiast zdecydowanie nie poleca używać indyga, gdyż w spoiwie olejnym traci kolor, E. Berger, op. cit., s. 105-119. Nie jest wykluczone, że pigmenty, których nie zidentyfikowano, np. żółcień ołowiowo-cynowa, ultramaryna czy indygo, występują w tych partiach obrazu, z których nie pobrano próbek, np. w detalach postaci sztafażu.

${ }_{14}$ M. Roznerska, Techniki malarskie „malych mistrzón bolenderskich” XVII w., Toruń 1991, s. 170.

15 Ibidem, s. 181.

16 J. Rogóż, Fotografia kolorowa w bliskiej podczerwieni - „technika fatssynyych kolorón”, [w:] Od badań do konserwacji. Materialy konferencii, Toruń 23-24 października 1998, Toruń 2002, s. 225-235. Interpretacji fotografii w technice „fałszywych kolorów” dokonano na podstawie konsultacji z dr. hab. J. Rogóżem oraz powyższej publikacji.

17 De Mayerne wymienia przede wszystkim trzy rodzaje olejów stosowanych w jego czasach: lniany, orzechowy i makowy, za najlepszy z nich uznając lniany, który w przeciwieństwie do makowego i orzechowego, pozostawiony na słońcu ulega rozjaśnieniu. E. Berger, op. cit., s. 107, 309. W swoich rozmowach z de Mayerne'em van Dyck uznał olej lniany za najlepszy ze wszystkich. Podobnie uważał Rubens, choć używał także oleju orzechowego, który ze względu na mniejszą tendencję do żółknięcia polecany był jako spoiwo do pigmentów podatnych na żółknięcie w spoiwie olejnym, przede wszystkich bieli i błękitów, J. Kirby, op. cit., s. 32.

18 Dodatek żywicy sosnowej, terpentyny weneckiej (czyli balsamu na bazie żywicy modrzewiowej) czy mastyksu do spoiwa olejnego przypisywany jest m.in. Rubensowi i van Dyckowi. Medium olejno-żywiczne (odpowiednio modyfikowane, np. sykatywami, sposo- 
Ze względu na zbyt małą ilość próbek nie udało się zidentyfikować rodzaju oleju oraz użytej żywicy. Najprawdopodobniej użyto oleju lnianego, makowego lub orzechowego, natomiast z żywic - mastyksu. Możliwy jest także dodatek terpentyny weneckiej. Również nie było możliwości wykazania dodatku sykatywy do spoiwa, która zresztą malarzowi nie była prawdopodobnie potrzebna ze względu na obecność pigmentów przyspieszających schnięcie oleju, a więc bieli ołowiowej, miedzianki i smalty ${ }^{19}$.

Tabela 1. Wyniki badań Potycžki jeźdźcón w krajobrażie

\begin{tabular}{|c|c|c|c|}
\hline Nazwa warstwy & & Skład warstwy & Grubość warstwy \\
\hline Podobrazie & \multicolumn{2}{|c|}{$\begin{array}{l}\text { drewniane: dwie deski dębowe } 0 \text { wymiarach } 8 \text { × } 41 \mathrm{~cm} \text { i } 24,5 \times 41 \\
\mathrm{~cm} \text {, cięte promieniowo, sklejone na styk }\end{array}$} & ok. $1 \mathrm{~cm}$ \\
\hline \multirow[t]{2}{*}{ Zaprawa } & Spoiwo & Pigmenty & \multirow{2}{*}{$\begin{array}{l}28-126 \mu m \text { (śred- } \\
\text { nia grubość warstwy } \\
77 \mu \mathrm{m})\end{array}$} \\
\hline & $\begin{array}{l}\text { klejowe (klej glutyno- } \\
\text { wy?) }\end{array}$ & $\begin{array}{l}\text { kreda } \mathrm{CaC} 03 \text {, biel ołowiowa } 2 \mathrm{PbC0} \bullet \bullet- \\
\mathrm{b}(\mathrm{OH}) 2\end{array}$ & \\
\hline $\begin{array}{l}\text { Miejscowe podmalowanie } \\
\text { - wstępny rysunek lawowany (?) }\end{array}$ & olejne (olej schnący) & $\begin{array}{l}\text { ugier Fe203•nH20, czerwień żelazowa } \\
\text { Fe203, czerń organiczna - sadza }\end{array}$ & $\leq 14$ \\
\hline $\begin{array}{l}\text { Warstwa malarska: } \\
\text { — niebo (półton) } \\
\text { — listowie drzew } \\
\text { — pień drzewa } \\
\text { — pejzaż na horyzoncie }\end{array}$ & $\begin{array}{l}\text { olejne (olej schnący) } \\
\text { i olejno-żywiczne }\end{array}$ & 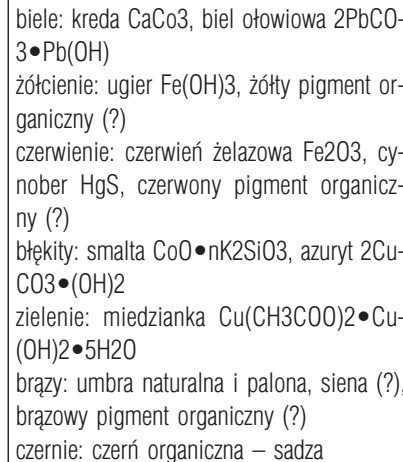 & $\begin{array}{l}14-98 \mu \mathrm{m} \\
\text { (średnia grubość } \\
\text { warstwy: } 56 \mu \mathrm{m} \text { ) }\end{array}$ \\
\hline
\end{tabular}

bami przygotowania oleju czy wreszcie stosunkiem ilości żywicy do spoiwa olejnego) miało zastosowanie głównie w laserunkach, czyniąc je jeszcze bardziej transparentnymi, dodawało blasku i nasycenia kolorom oraz podkreślało głębię w partiach cieni. Jedna ze wskazówek Rubensa, zawarta w traktacie de Mayerne'a, wskazuje na to, że artysta maczał pędzle w terpentynie weneckiej, a następnie używał ich do nakładania błękitów oraz innych farb - był to jego sposób na to, aby farby dawały się dobrze nakładać i nie blakły, por. J. Kirby, op. cit., s. 32; E. Berger, op. cit., s. 115; J. Hopliński, Farby i spoiwa malarskie, Wrocław 1990, s. 49; M. Doerner, Materialy malarskie i ich zastosowanie, Warszawa 1975, s. 223-224.

19 P. Rudniewski, Pigmenty $i$ ich identyfikeacja, Skrypt 13, ASP w Warszawie, Warszawa 1994, s. $35,59,71$. 
Poszczególne warstwy malarskie nakładane były w sposób spontaniczny i zdecydowany, śmiałymi pociagnięciami pędzla, o czym świadcza pozostawione dukty. Już sam charakter opracowania poszczególnych elementów składowych kompozycji wskazuje, że obraz wykonany został dość pospiesznie i choć sprawia wrażenie w całości wykonanego metodą alla prima, wnikliwa analiza wizualna i badania przekrojów stratygraficznych wykazuja obecność miejscowych podmalówek: błękitnej w partii nieba i pejzażu na horyzoncie oraz ugrowej w partii ziemi. Przekroje wskazuja na występowanie co najwyżej dwóch warstw na jasnobłękitnej podmalówce, możliwe jednak, że jest ich więcej w innych miejscach malowidła. Świetlistość i żywy koloryt barw jest między innymi wynikiem użycia przez malarza białej zaprawy $^{20}$ oraz kombinacji warstw kryjących i laserunkowych na bazie spoiwa olejno-żywicznego, na co wskazuje analiza wizualna partii zarośli dalszego planu i ziemi. Natomiast fakt, że nie na wszystkich przekrojach stratygraficznych próbek widoczny jest podział między warstwami malarskimi, nasuwa przypuszczenie, iż niektóre warstwy nanoszone były również metoda , mokro w mokrym” - artysta od razu tworzył modelunek form, nakładając farbę poprzez kilka nawarstwień. Tak jest prawdopodobnie w przypadku sztafażu, który namalowany został alla prima na wykonanym uprzednio podmalowaniu krajobrazu. Zatem można zaryzykować stwierdzenie, że większa część obrazu została namalowana w technice alla prima, natomiast na etapie wykończeniowym malarz mógł dodatkowo wzbogacić warstwę malarską laserunkami. Możliwe również, że wspomniany układ warstw, widoczny na przekrojach, nie zawsze był celowym założeniem artysty, a wynikiem szybkiego wysychania warstw spodnich. Wykazano bowiem duży udział bieli ołowiowej niemal we wszystkich warstwach, zwłaszcza w jasnobłękitnej podmalówce, a także zieleni miedziowej i smalty, a więc, jak

20 E. Basiul, Droga powstawania okereślonych efektón kolorystycznych na powierzçni obrazón štalugonych, „AUNC. Zabytkoznawstwo i Konserwatorstwo” XXXII, Toruń 2002, s. 26. Autorka pisze: „biały podkład znacznie wzmacnia nasycenie barwy. Na takim podłożu światło dwukrotnie przenika warstwę farby i wielokrotnie ulega licznym odbiciom na powierzchniach granicznych czastek. W celu osiagnięcia odpowiedniej głębi i świetlistości barwy wierzchniego laserunku należy właściwie dobrać farby. Najlepsze efekty dają farby typowo laserunkowe. Rozrzedzone spoiwem czy rozcieńczalnikiem farby o charakterze kryjącym będa transparentne, ale pozbawione intensywności barwnej”. 
już wcześniej wspomniano, pigmentów mających sykatywujące właściwości. Artysta mógł również używać specjalnie przygotowanego szybkoschnącego spoiwa olejnego lub olejno-żywicznego, a także dodatkowo użyć sykatywy do farb - nie udało się jednak tego zbadać.

\section{Technika i technologia}

\section{Krajobrazu ze sztafażem batalistycznym}

\section{z Muzeum Narodowego w Gdańsku oraz} Potyczki z Muzeum Narodowego w Warszawie

Drewniane podobrazie Pejzaż batalistycznego ze sztafażem z Muzeum Narodowego w Gdańsku, prawdopodobnie dębowe, składa się z dwóch promieniowo wyciętych desek sklejonych na styk.

Sądząc po śladach na licu, również drewniane podobrazie Potyczki z Muzeum Narodowego w Warszawie stanowią dwie sklejone deski. Na obu malowidłach zauważono „przebijające” przez warstwę malarską na całej powierzchni lica ziarenka wypełniaczy zaprawy koloru białego. Trudnością okazało się ustalenie obecności imprimatury, natomiast na podstawie obserwacji lica można przypuszczać, że podobnie jak w Potycze jeźdł́ćón w krajobrazie z poznańskiego muzeum, tak i tutaj występują lokalne podmalowania - w obu obrazach zastosowano półkryjące i transparentne podmalowania partii ziemi i krajobrazu jasnym brazem. Kształtowanie form polegało na laserunkowym i półkryjącym zaznaczeniu cieni i rozbielaniu kolorów lokalnych w światłach. Następnie na wierzch naniesiono detale graficzne, a najwyższe światła impastowo podkreślono bielą, niekiedy o odcieniu szarym bądź ugrowym. Niebo prawdopodobnie zostało podmalowane błękitem lub błękitną szarością i rozbielone w światłach, w miejscach obłoków impastowo, z pozostawieniem wyraźnych duktów pędzla. W obu przypadkach elementy sztafażu zostały naniesione we wcześniej wykreowany pejzaż, o czym świadcza prześwity pejzażowego tła przez miejscami transparentnie malowane postacie. Zauważono, że metoda kształtowania form listowia w analizowanych obrazach Pietera Meulenera jest podobna: poszczególne listki artysta modelował dekoracyjnie, pojedynczymi uderzeniami pędzla, różnicując grubość nakładanej farby z pozostawieniem widocznej faktury. 
W opracowywaniu najdrobniejszych detali listowia, zwłaszcza w światłach, widoczne są ślady pędzla o specjalnie rozszczepionej końcówce. Podobnie jak w przypadku poznańskiego obrazu, charakterystyczną cechą malowideł jest swobodne i wrażeniowe potraktowanie elementów kompozycji, głównie widoczne w przypadku modelunku ziemi i postaci sztafażu.

\section{Zakończenie}

Warsztat malarski Pietera Meulenera wykazuje cechy charakterystyczne dla flamandzkiego malarstwa XVII wieku, a artysta nawiązywał pod względem techniki i technologii do najlepszych malarzy swoich czasów. Brak imprimatury oraz wyraźnych śladów wstępnego zarysu kompozycji w Potycžce jeźdźców w krajobrazie z poznańskiego muzeum dowodzi jedynie ogromnego doświadczenia i pewnej dozy spontaniczności w działaniach artysty. Chcąc zapewne przyspieszyć prace, Meulener stosował odpowiednie warstwy tonujące - błękitną w partii nieba i jasnobrązową w pejzażu. Mimo obecności tych podmalówek i miejscowych laserunków, można wysunać ogólny wniosek, że obrazy, zgodnie z coraz bardziej popularna w tych czasach włoską maniera fa presto, namalowano metoda zbliżona do alla prima. Zarówno Rubensowi jak i van Dyckowi przypisywane jest powiedzenie: „Próbuj dopóki możesz, wszystko wykańczać alla prima, i tak pozostanie ci jeszcze wiele do zrobienia"21. Szkicowe i wrażeniowe formowanie poszczególnych elementów kompozycji, widoczne zwłaszcza w postaciach sztafażu, pozostawianie wyraźnych śladów pędzla - oto cechy, które ujawniaja temperament artysty, wręcz pewien pośpiech, w jakim być może pracował Meulener. Taki sposób malowania jest już dość daleki od pracochłonnego, wielowarstwowego opracowania typowego dla malarstwa staroniderlandzkiego. Należy również dodać, że wspomniana szkicowość i lekkość prowadzenia pędzla u Meulenera bliskie sa nowatorskiej swobodzie kształtowania form malarskich widocznej np. w obrazach Mompera czy nawet Rubensa. Natomiast obrazy innych współczesnych Meulenerowi artystów specjalizują-

21 M. Doerner, op. cit., s. 225. 
cych się w pejzażach ze sztafażem, takich jak A. Govaerts, A. van Stalbemt oraz batalistów - P. Snayersa i S. Vrancxa, w porównaniu z obrazami Pietera Meulenera wykazuja bardziej schematyczny modelunek. Dotyczy to również batalistycznych przedstawień działającego w II poł. XVII wieku domniemanego naśladowcy Meulenera - Adama Fransa van der Meulena.

\section{Summary}

\section{Painting workshop of Pieter Meulener based on examination of the painting "Battles of the riders in the landscape" (1647) from the National Museum in Poznan and on other artist's works in the Polish collections}

This paper presents technique and technology of the seventeenth-century Flemish painter Pieter Meulener, most renowned for battle scenes and landscapes with scenes. It presents an analysis of the technical structure: Encounter of Horsemen in a landscape from the collection of the National Museum in Poznan, Skirmish from the National Museum in Warsaw and Landscape with a battle scene from the National Museum in Gdansk. The presented results were supplemented with information on the seventeenth century Flemish painters' workshop.

Analysis on the technical structure of Pieter Meulener's paintings helped to understand the rules in seventeenth century Flemish painting. In result of this research it was established that Pieter Meulener referred in his painting to the workshop of the best painters of his time. The impact of emerging new trends in painting, such as alla prima technique and the strong impact of Rubens innovation and his rich painting expression, and thus - drifting away from the established painting routines - have set a very interesting stage in the evolution of Flemish paintings techniques and technologies, which due to some open issues can be an inspiration for further research. 


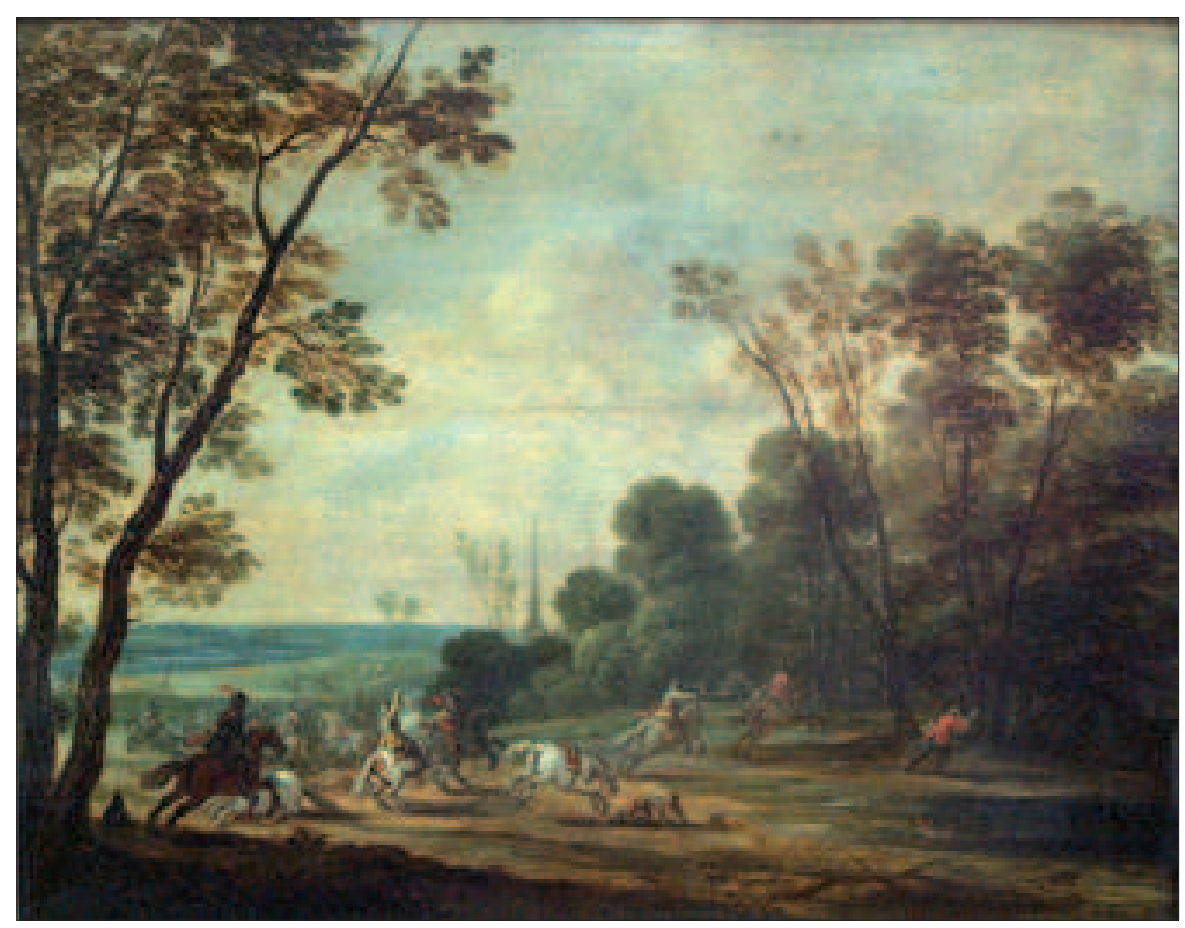

Il. 1. Pieter Meulener, Potyczka jeźdźców w krajobrazie, 1647 r., Muzeum Narodowe w Poznaniu (fot. A. Cupa)

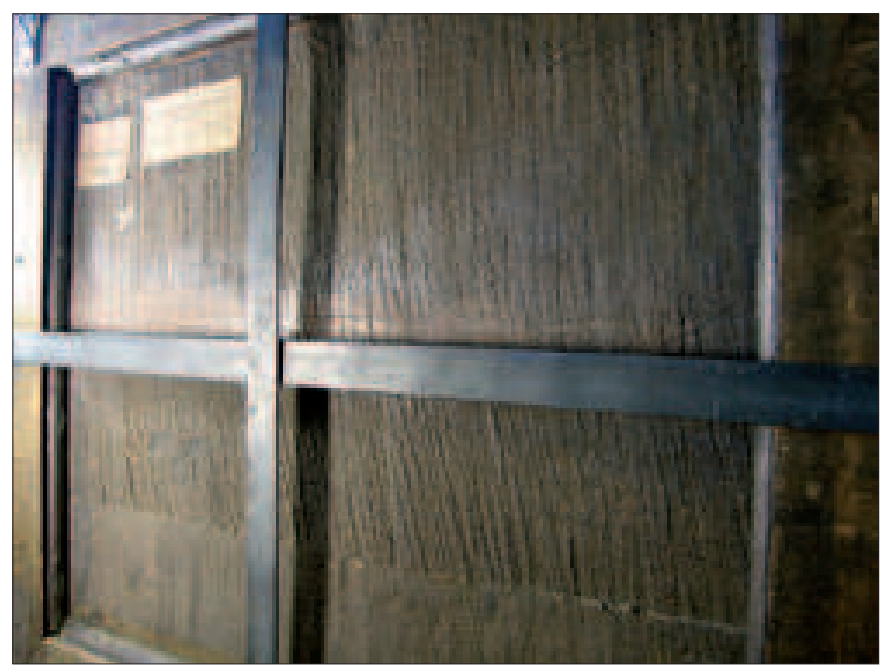

Il. 2. Pieter Meulener, Potyczka jeźdźców w krajobrazie, 1647 r., Muzeum Narodowe w Poznaniu. Fotografia odwrocia obrazu (fot. M. Kapka) 


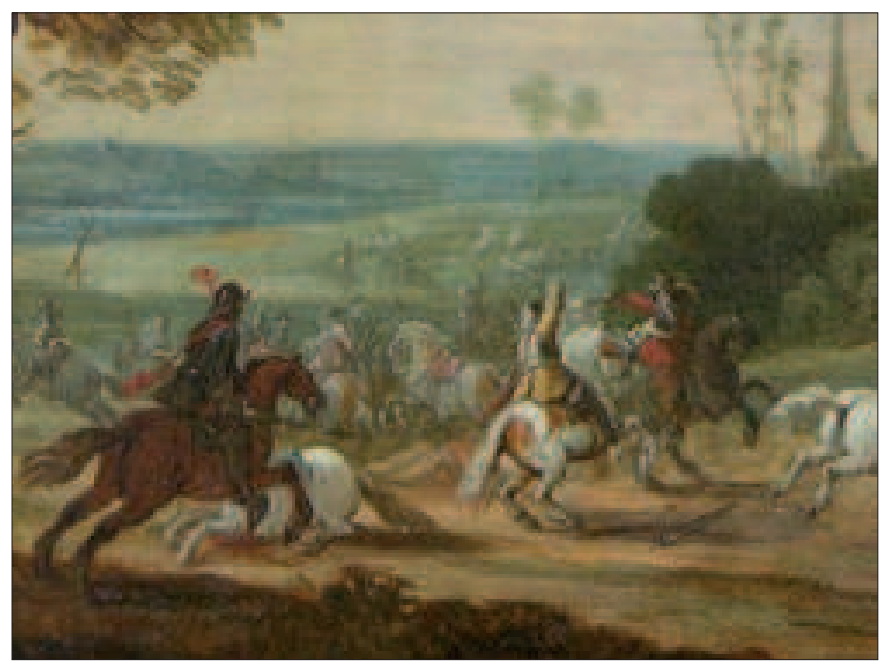

Il. 3. Pieter Meulener, Potyczka jeźdźców w krajobrazie, 1647 r., fragment (fot. M. Kapka)

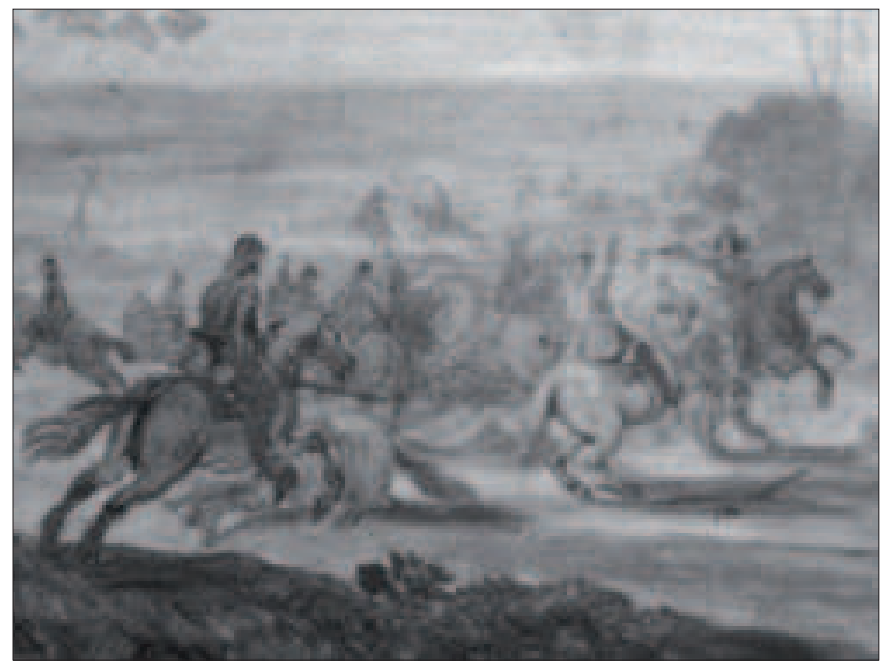

Il. 4. Pieter Meulener, Potyczka jeźdźców w krajobrazie, 1647 r., fragment. Reflektografia IR (fot. A. Cupa) 


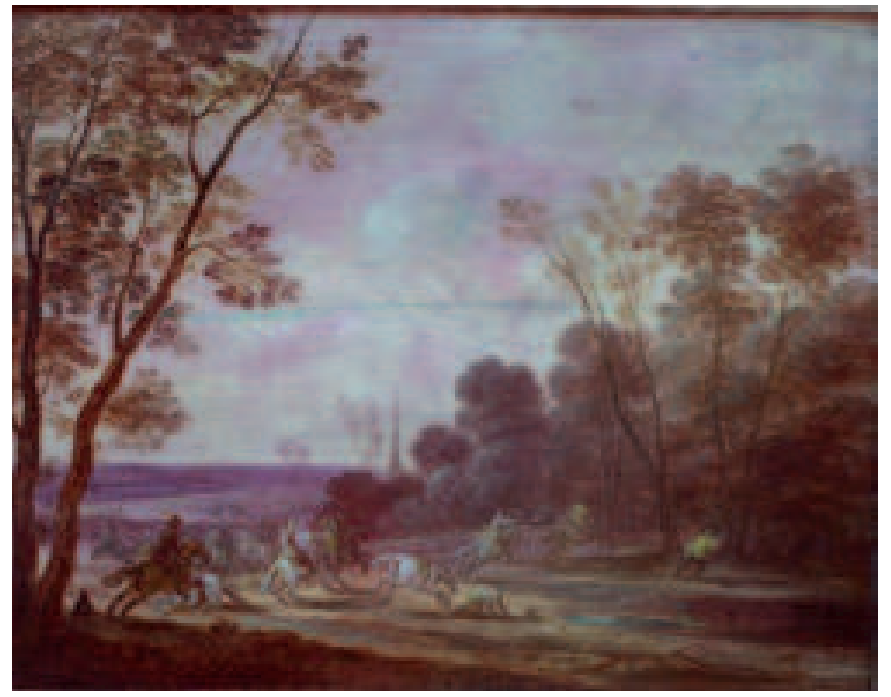

Il. 5. Pieter Meulener, Potyczka jeźdźców w krajobrazie, 1647 r. Fotografia kolorowa w podczerwieni (fot. A. Cupa) 


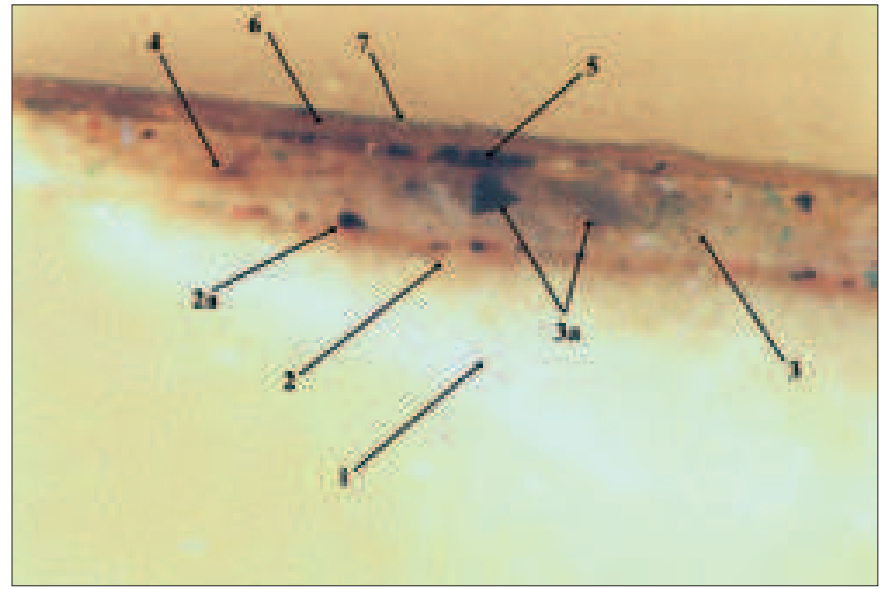

Il. 6. Przekrój stratygraficzny jednej z próbek - zieleń z partii roślinności (prawa część kompozycji). Fotografia mikroskopowa w świetle VIS, pow. $500 \mathrm{x}$ (fot. Z. Rozłucka)

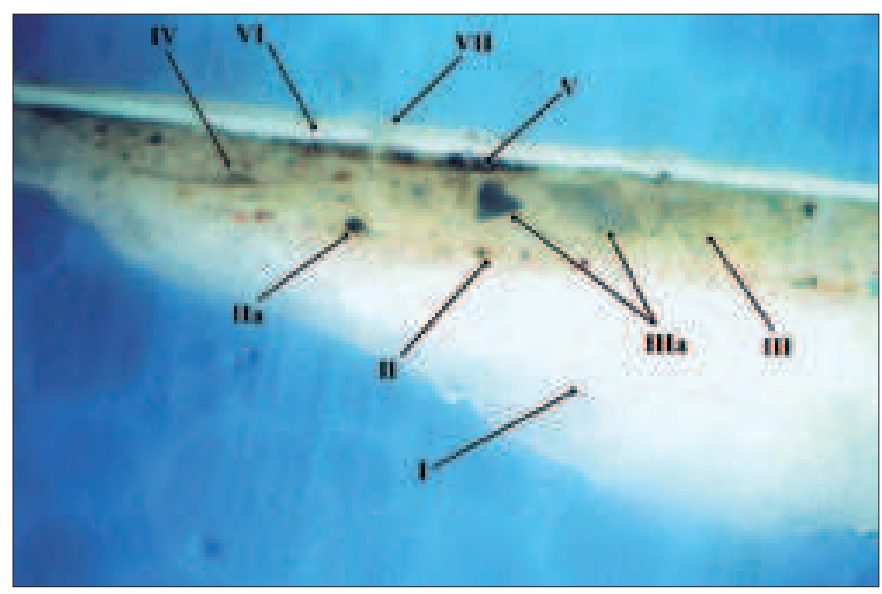

Il. 7. Przekrój stratygraficzny jednej z próbek - zieleń z partii roślinności (prawa część kompozycji). Fotografia mikroskopowa w świetle UV, pow. 500 x (fot. Z. Rozłucka) 


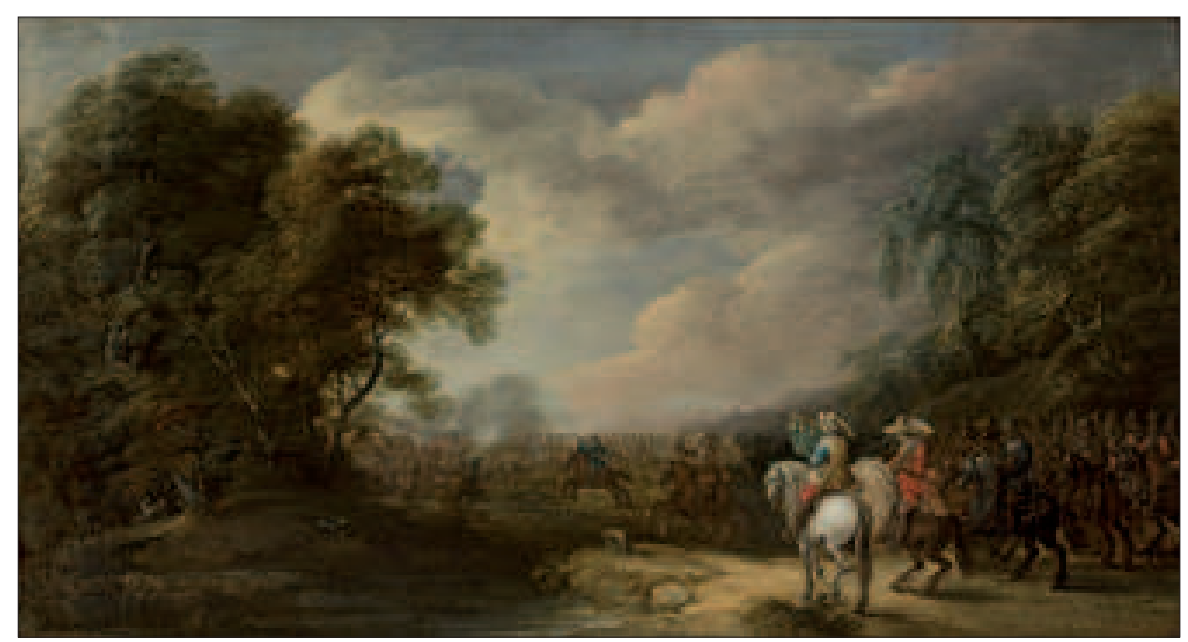

Il. 8. Pieter Meulener, Krajobraz ze sztafażem batalistycznym, 1646 r., Muzeum Narodowe w Gdańsku (fot. Muzeum)

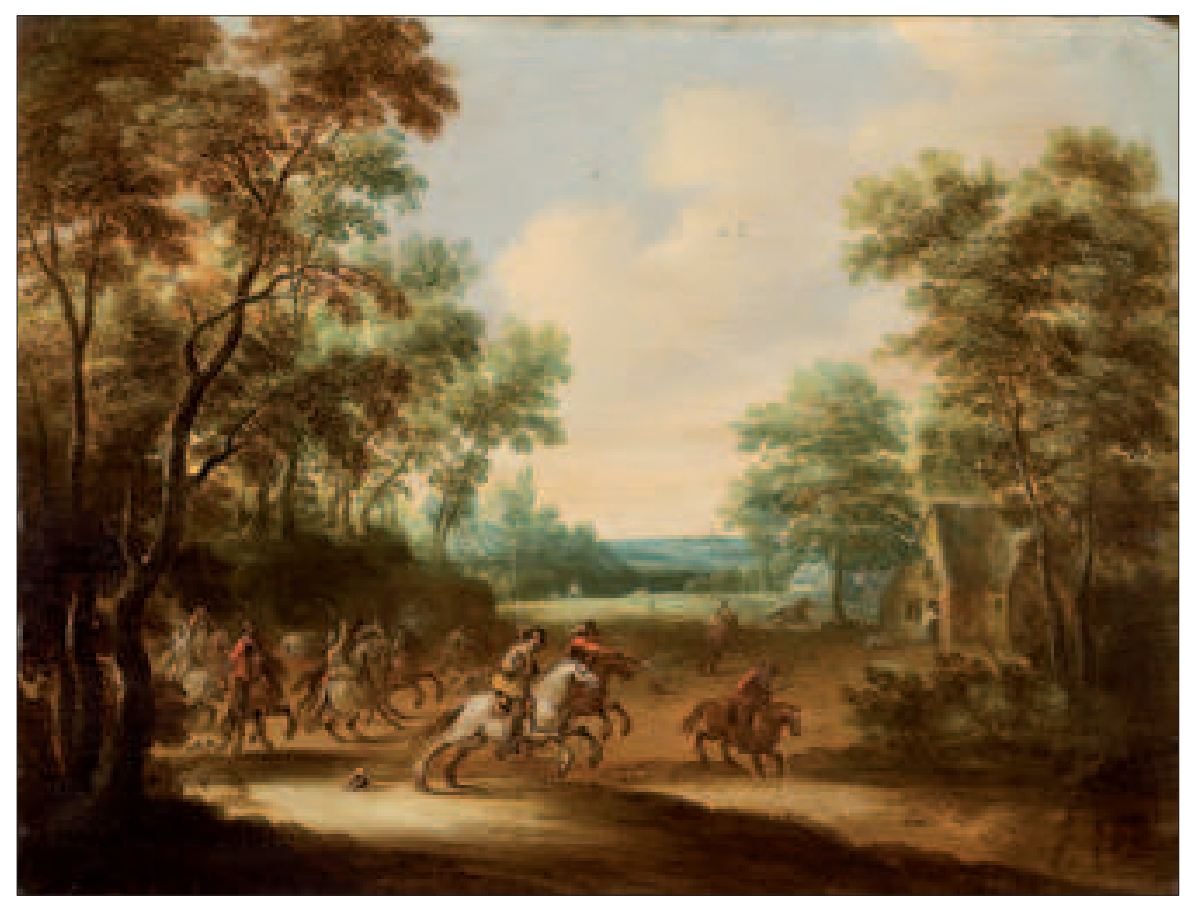

Il. 9. Pieter Meulener, Potyczka z Muzeum Narodowego w Warszawie (fot. Krzysztof Wilczyński/Ligier Studio) 


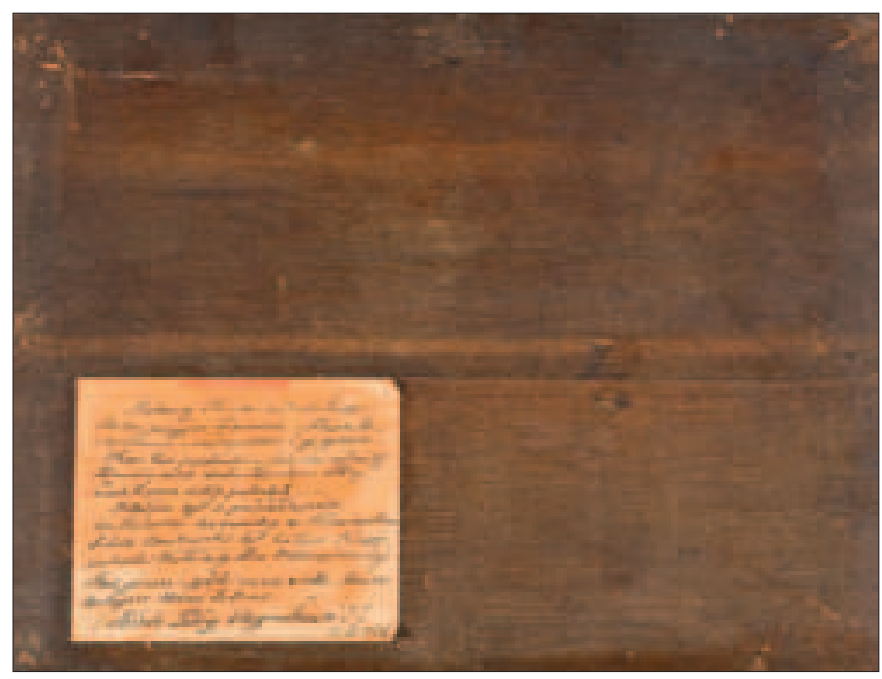

Il. 10. Pieter Meulener, Krajobraz ze sztafażem batalistycznym, 1646 r., Muzeum Narodowe w Gdańsku, fotografia odwrocia. Widoczne miejsce sklejenia dwóch desek oraz sfazowanie przy krawędziach obrazu (fot. Muzeum)

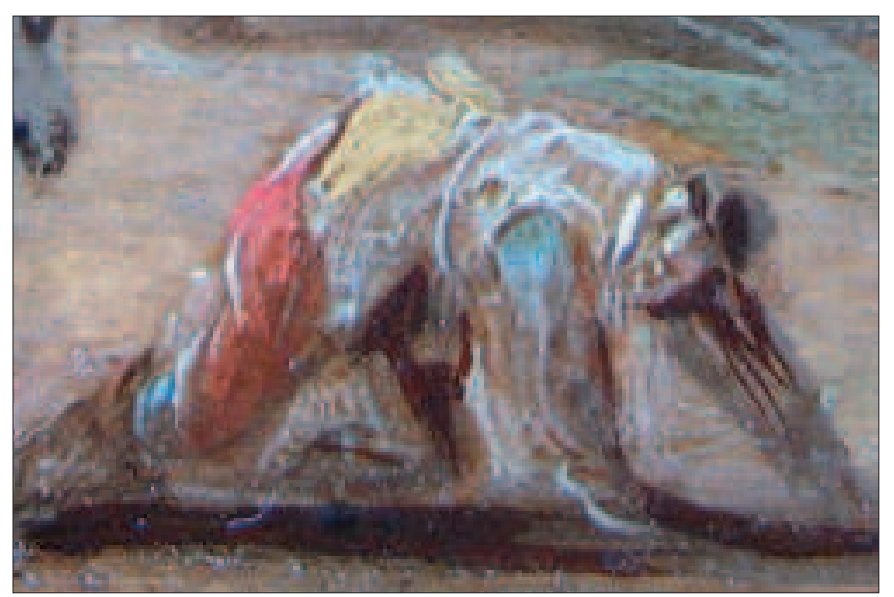

Il. 11. Pieter Meulener, Potyczka jeźdźców w krajobrazie, 1647 r., detal - makrofotografia. Przykład szkicowego opracowania postaci sztafażu (fot. M. Kapka) 


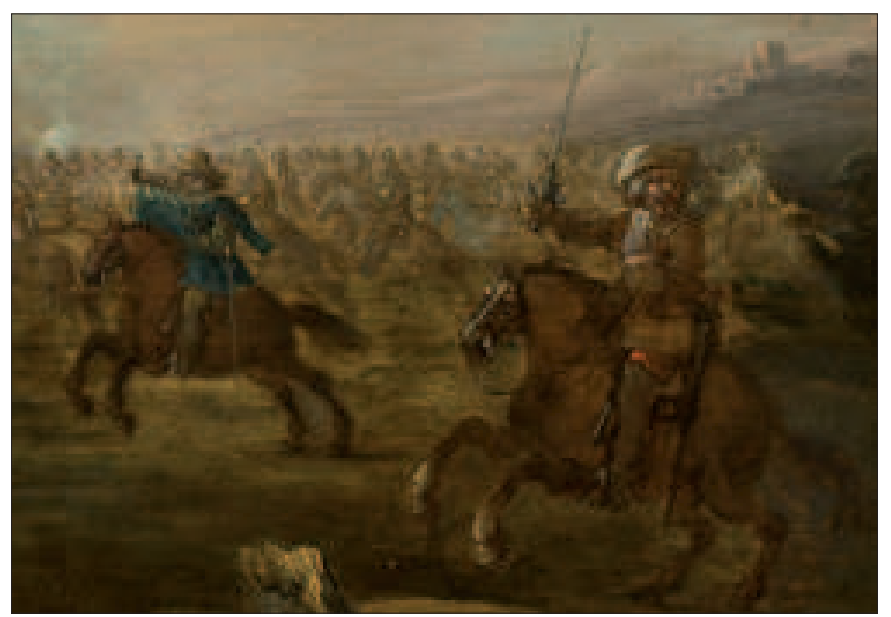

Il. 12. Pieter Meulener, Potyczka, Muzeum Narodowe w Warszawie, fragment (fot. Krzysztof Wilczyński/Ligier Studio)

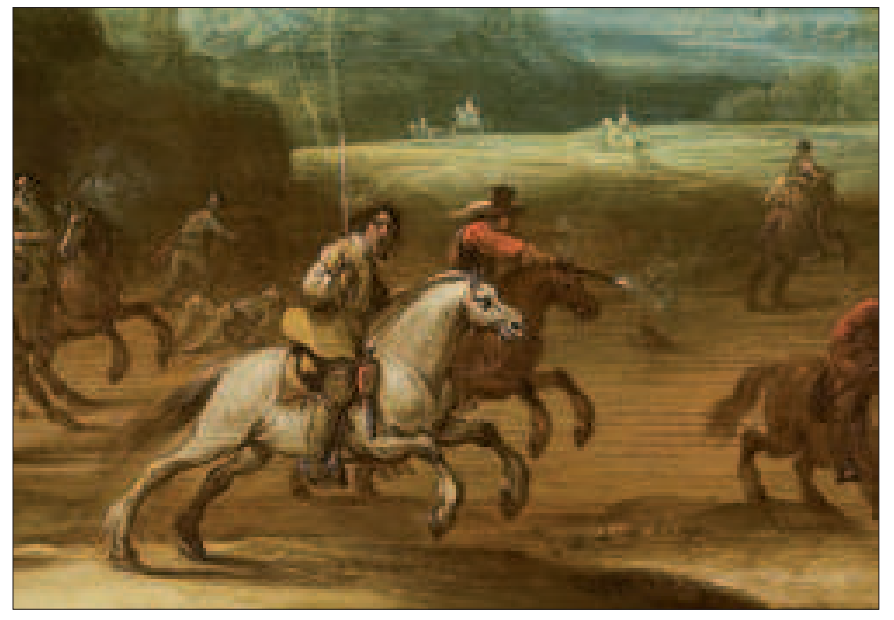

Il. 13. Pieter Meulener, Krajobraz ze sztafażem batalistycznym, 1646 r., Muzeum Narodowe w Gdańsku, fragment (fot. Muzeum) 